\title{
Structural Behaviour of Shredded Waste Paper Reinforced Concrete Beam
}

\author{
S. Azuwa and F.M. Yahaya* \\ Faculty of Civil Engineering Technology, Universiti Malaysia Pahang, Lebuhraya Tun Razak, 26300 Gambang, \\ Kuantan, Pahang Darul Makmur, Malaysia \\ *Email: fadzil@ump.edu.my
}

\begin{abstract}
Cement, sand, coarse aggregate, water and reinforcing bar are the materials to make a reinforced concrete beam. The waste paper has been dumped as waste and causes environmental pollution behind mill or landfill. The industry paper wastage for every year is increasing gradually. More spaces are being needed for landfills, uses energy loss of natural resources and increase of expenditure and various types of pollutions. Utilizing waste paper as an addition to reinforced concrete beam production will reduce environmental pollutions. This research is conducted to investigate the structural behaviour of reinforced concrete beam containing $10 \%$ shredded mixed and cardboard waste paper as additions in concrete with three types of reinforcements such as full shear reinforcement with stirrup spacing $(\mathrm{SS}=100 \mathrm{~mm}$ ) and reduced shear reinforcements with stirrup spacing $(\mathrm{SS}=150 \mathrm{~mm})$ and (SS=200 mm). All specimens are subjected to air curing at 28 days. The results of load-deflection behaviour and ultimate load-bearing capacity are better with $10 \%$ shredded copier and cardboard waste paper at 28 days of air curing with full and reduced shear reinforcements. The finding shows that reinforced concrete beam with full shear reinforcement with $\mathrm{SS}=100 \mathrm{~mm}$ containing $10 \%$ addition of shredded cardboard waste paper in concrete exhibits the highest load at yield $(\mathrm{Py}=96.67 \mathrm{kN})$, ultimate load $(\mathrm{Pu}=103.15 \mathrm{kN})$, maximum load $(\mathrm{Pmax}=106.78 \mathrm{kN})$ representing the load-carrying capacity, load at first crack $\left(\mathrm{P}_{1}=70.84 \mathrm{kN}\right)$ and the lowest yield deflection $(\delta \mathrm{y}=11.98 \mathrm{~mm})$, ultimate deflection $(\delta \mathrm{u}=23.04 \mathrm{~mm})$, maximum deflection $(\delta \mathrm{max}=18.12 \mathrm{~mm})$ compared to $10 \%$ SCPWP and $0 \%$. This study indicates that shredded copier and cardboard waste paper can be used as additional material in reinforced concrete beam production.
\end{abstract}

Index Terms- Reinforced Concrete Beam, Shredded Waste Paper, Load-Deflection, Ultimate Load Bearing Capacity

\section{INTRODUCTION}

Reinforced concrete is widely used in the construction industry due to its advantages such as strong, robust, economical and durable. Nowadays, carbon dioxide $\left(\mathrm{CO}_{2}\right)$ gas emissions from houses are attributed to cement usage, which is a massive issue for all nations. Consequently, people's crave for eco-living is increasing. This research is conducted to address these kinds of problems. Using waste paper in concrete can produce a new and modern construction material. By using waste paper, the cement amount used reduces as it provides an environmentally friendly construction material [1]. Portland cement and waste paper are the materials that make a fibrous cemented material called papercrete. Papercrete might be a material initially developed 80 years ago that has recently been rediscovered. It should be noted that papercrete has a limited-range concept [2]. For decades, as alternative building material stated by (Fuller et al., 2006) [2], a committed environmentalist has designed homes and structures made of cement, other materials and waste paper. They argued that this papercrete structure is perfect and durable for insulating and durability. A paper reinforced structure is a structurally and economically viable alternative based on the indicated result within a range of size [3]. Portland cement or clay with re-pulped paper fibre develop a new construction material that called papercrete. They identified their discovery of adobe and fibrous cement and found themselves 
independently [4].

Due to the alternative building material known as papercrete, the dead load of the main structure can be diminished [5]. Water and any types of papers such as cardboard, sparkling magazine stock, daily paper, waste mail advertising or any other types of papers are the fundamental components of papercrete. The paper mill produces most of the paper recycling works $[6,7,8,9,10,11]$ or to manufacture cement board $[12,13]$. Other than that, it can end up a reasonable and productive substitute in landfills, incinerators, or other utilize choices [14]. Moreover, waste paper can be used in the right way by using it in construction materials to reduce its density, as stated by (Yogesh and Mahaveer, 2017) [15]. The building expenses can be reduced by measuring the quality, workability, and other papercrete properties [16]. Furthermore, due to its lightweight characteristic, papercrete can also be used for the interior wall of a high-rise building in seismically active regions [16]. Moreover, papercrete usage will decrease the dead load of the structure, the depth of foundation required, and the percentage of steel used, so the labour amount and energy expense will be decreasing significantly [17]. Papercrete can grant numerous benefits and wide utilization in concrete. In addition to that, papercrete persuades waste paper recycling, particularly in a community without recycling activity. It cuts the waste space, holds paper production and chemical printing out of the water table [18]. From previous research, shredded copier and cardboard waste paper have never been used in a reinforced concrete beam (RCB) structural application. So, this research aims to investigate the structural behaviour of RCB containing three different types of concrete mixtures. There are $0 \% \mathrm{C}, 10 \%$ addition of shredded copier waste paper (SCPWP) and 10\% addition of shredded cardboard waste paper (SCBWP) in the concrete mixture. The investigated structural behaviour of the RCB is load-deflection and ultimate load bearing capacity.

\section{MATERIALS AND METHODS}

This research uses cement, sand, coarse aggregate, water, shredded mixed and cardboard waste papers. Ordinary Portland Cement (OPC) used Orang Kuat brand produced by YTL Cement Marketing Sdn. Bhd. to ensure the cement has the same chemical compositions and physical properties as shown in Table 1 [19]. This type of cement follows [20] for Portland cement specifications. A local supplier supplied the river sand used in this study. It was obtained from the concrete laboratory at the Faculty of Civil Engineering Technology, Universiti Malaysia Pahang (UMP). The sand used as fine aggregate. Physical properties of sand meet the requirements of (British Standard, 1992) [21]. Gravel was used as coarse aggregate in this research. The minimum and maximum sizes of gravel are $5 \mathrm{~mm}$ and $20 \mathrm{~mm}$. The gravel physical properties meet the prerequisites of (British Standard, 1992) [21]. The concrete grade used in this research is Grade 30. The reinforcing bars used for compression and tension are $2 \mathrm{Y} 12$ and $2 \mathrm{Y} 16$ while for the stirrup is R6. Copier and cardboard waste paper were used in this research by collecting them from the office. Both types of paper were then shredded using a paper shredder machine. All sizes and dimensions of shredded waste paper (SWP) used in this research were the same after shredded. Figure 1 and 2 show the shredded copier waste paper (SCPWP) and shredded cardboard waste paper (SCBWP) used in this research.

Table 1: Chemical compositions and physical properties of OPC [19]

\begin{tabular}{|c|c|c|c|}
\hline Test & Unit & $\begin{array}{c}\text { Specification MS-522-1: } \\
2007(42.5 \mathrm{~N})\end{array}$ & Test result \\
\hline & & Chemical compositions & \\
\hline Insoluble residue & $\%$ & $\leq 5.0$ & 0.40 \\
\hline Loss on ignition $(\mathrm{LOI})$ & $\%$ & $\leq 5.0$ & 0.32 \\
\hline Sulfate content $\left(\mathrm{SO}_{3}\right)$ & $\%$ & $\leq 3.5$ & 2.70 \\
\hline Chloride $(\mathrm{Cl})$ & $\%$ & Physical properties & 0.02 \\
\hline & & - & 345 \\
\hline Fineness & $\mathrm{m}^{2} / \mathrm{kg}$ & $\geq 60$ & 130 \\
\hline Setting time (inial) & $\mathrm{min}$ & $\leq 10$ & 1.00 \\
\hline Soundness & $\mathrm{mm}$ & & \\
\hline
\end{tabular}




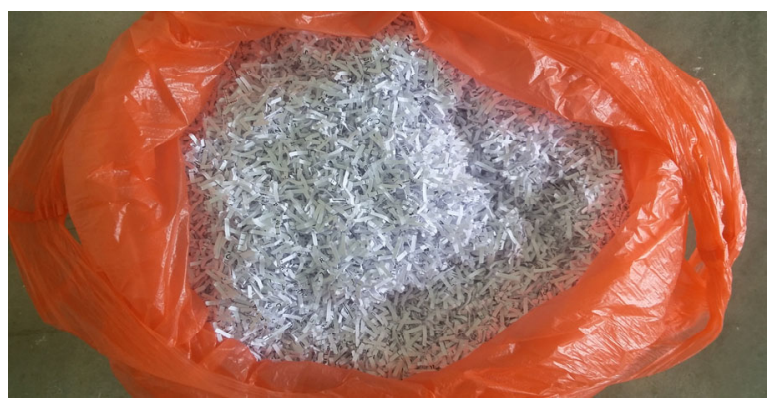

Figure 1: Shredded copier waste paper (SCPWP)

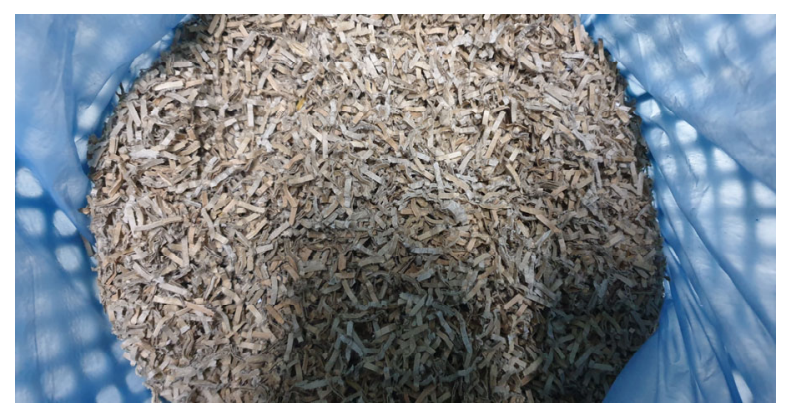

Figure 2: Shredded cardboard waste paper (SCBWP)

A paper is primarily made of wood cellulose fibre which is known to be a fibrous material. Cellulose is a genuine polymer made by smaller molecules composing associated sugar with a long chain. A sugar type: $\beta-\mathrm{D}$ glucose is the bonding of the cellulose chain. The polar-OH cellulose bristles make up many hydrogen bonds with $\mathrm{OH}$ groups to approach and bundle together the chains, as shown in Figure 3 $[22,23,24]$. The chains also pack in orderly places to form hard and strong regions of crystalline to enable more balance and strength in the bundled chains.

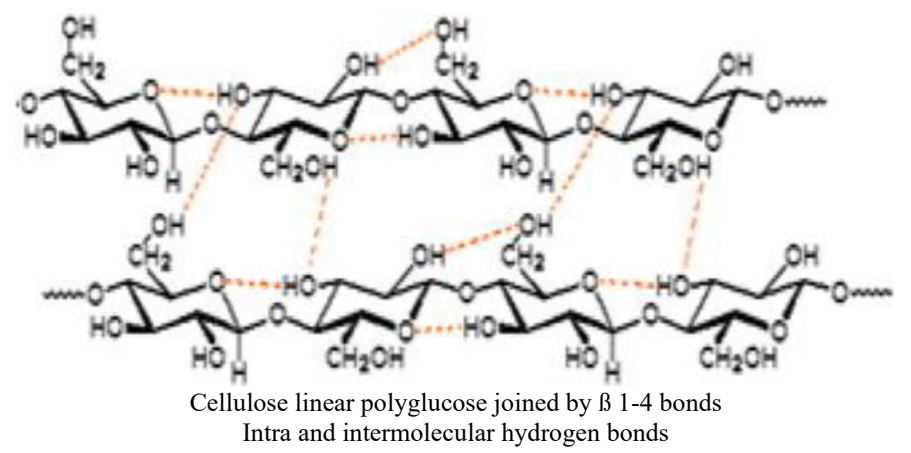

Figure 3: Paper chemical structure (cellulose hydrogen bond) [22,23,24]

Table 2 and Table 3 show the fibre properties of two types of waste paper before and after disintegration [25]. Table 4 and Table 5 show the strength properties of two types of waste paper before and after disintegration [25].

The mixing process of concrete was done by using standard concrete making procedures. The concrete was copier using a concrete mixer. Before mixing, all the specimens were weighed according to the mix design. SCPWP and SCBWP used as additions in concrete with $10 \%$ by weight of the mixture. The cement: sand: aggregate ratio used in this research is 1:0.75:1.5 by the weight of the materials, and 0.5 is the water to cement ratio used. This ratio is fixed for all specimens. This experiment 
uses 3 concrete mix proportions, as presented in Table 6 . Figure 4,5,6 show the RCB casting of $0 \% \mathrm{C}$, $10 \%$ SCPWP and $10 \%$ SCBWP concrete mixtures.

Table 2: Fibre properties before disintegration [25]

\begin{tabular}{|c|c|c|c|c|}
\hline $\begin{array}{c}\text { Type of waste } \\
\text { paper }\end{array}$ & $\begin{array}{c}\text { Fibre average } \\
\text { length }(\mathrm{mm})\end{array}$ & $\begin{array}{c}\text { Medium fibre } \\
\text { content (\%) }\end{array}$ & $\begin{array}{c}\text { Long fibre } \\
\text { content (\%) }\end{array}$ & $\begin{array}{c}\text { Fine fibre and } \\
\text { non-fibre } \\
\text { contents (\%) }\end{array}$ \\
\hline Copier & 0.40 & 12 & 16 & 66 \\
\hline Cardboard & 0.45 & 23 & 30 & 58 \\
\hline
\end{tabular}

Table 3: Fibre properties after disintegration [25]

\begin{tabular}{|c|c|c|c|c|}
\hline $\begin{array}{c}\text { Type of waste } \\
\text { paper }\end{array}$ & $\begin{array}{c}\text { Fibre average } \\
\text { length }(\mathrm{mm})\end{array}$ & $\begin{array}{c}\text { Medium fibre } \\
\text { content (\%) }\end{array}$ & $\begin{array}{c}\text { Long fibre } \\
\text { content (\%) }\end{array}$ & $\begin{array}{c}\text { Fine fibre and } \\
\text { non-fibre } \\
\text { contents (\%) }\end{array}$ \\
\hline Copier & 0.42 & 14 & 18 & 68 \\
\hline Cardboard & 0.47 & 25 & 32 & 60 \\
\hline
\end{tabular}

Table 4: Strength properties before disintegration [25]

\begin{tabular}{|c|c|c|c|c|c|}
\hline $\begin{array}{c}\text { Type of } \\
\text { waste paper }\end{array}$ & $\begin{array}{c}\text { Percentage } \\
(\%)\end{array}$ & $\begin{array}{c}\text { Bending } \\
\text { strength } \\
\left(\mathrm{N} / \mathrm{mm}^{2}\right)\end{array}$ & $\begin{array}{c}\text { Internal bond } \\
\left(\mathrm{N} / \mathrm{mm}^{2}\right)\end{array}$ & $\begin{array}{c}\text { Modulus of } \\
\text { elasticity } \\
\left(\mathrm{N} / \mathrm{mm}^{2}\right)\end{array}$ & $\begin{array}{c}\text { Thickness } \\
\text { swelling } \\
(\%)\end{array}$ \\
\hline Copier & 0 & 16 & 0.28 & 1600 & 3 \\
\hline & 5 & 20 & 0.31 & 1900 & 5 \\
\hline & 10 & 26 & 0.35 & 2300 & 10 \\
\hline & 15 & 10 & 0.23 & 1200 & 16 \\
\hline Cardboard & 0 & 16 & 0.28 & 1600 & 3 \\
\hline & 5 & 24 & 0.33 & 2100 & 7 \\
\hline & 10 & 28 & 0.39 & 2400 & 13 \\
\hline & 15 & 14 & 0.26 & 1300 & 18 \\
\hline
\end{tabular}

Table 5: Strength properties after disintegration [25]

\begin{tabular}{|c|c|c|c|c|c|}
\hline $\begin{array}{c}\text { Type of } \\
\text { waste paper }\end{array}$ & $\begin{array}{c}\text { Percentage } \\
(\%)\end{array}$ & $\begin{array}{c}\text { Bending } \\
\text { strength } \\
\left(\mathrm{N} / \mathrm{mm}^{2}\right)\end{array}$ & $\begin{array}{c}\text { Internal bond } \\
\left(\mathrm{N} / \mathrm{mm}^{2}\right)\end{array}$ & $\begin{array}{c}\text { Modulus of } \\
\text { elasticity } \\
\left(\mathrm{N} / \mathrm{mm}^{2}\right)\end{array}$ & $\begin{array}{c}\text { Thickness } \\
\text { swelling } \\
(\%)\end{array}$ \\
\hline Copier & 0 & 18 & 0.30 & 1800 & 5 \\
\hline & 5 & 22 & 0.33 & 2100 & 7 \\
\hline & 10 & 28 & 0.37 & 2500 & 12 \\
\hline Cardboard & 15 & 12 & 0.25 & 1400 & 18 \\
\hline & 0 & 18 & 0.30 & 1800 & 5 \\
\hline & 5 & 26 & 0.35 & 2300 & 9 \\
\hline & 10 & 30 & 0.41 & 2600 & 15 \\
\hline & 15 & 16 & 0.28 & 1500 & 20 \\
\hline
\end{tabular}


Table 6: Concrete mix proportion

\begin{tabular}{|c|c|c|c|c|c|}
\hline $\begin{array}{c}\text { Concrete } \\
\text { mixture }\end{array}$ & Cement (Kg) & Sand (Kg) & $\begin{array}{c}\text { Coarse } \\
\text { aggregate }(\mathrm{Kg})\end{array}$ & $\begin{array}{c}\text { Shredded waste } \\
\text { paper (SWP) } \\
(\mathrm{Kg})\end{array}$ & $\mathrm{W} / \mathrm{C}$ \\
\hline $0 \% \mathrm{C}$ & 75 & 56.25 & 112.5 & 0 & 0.5 \\
\hline $10 \%$ SCPWP & 75 & 56.25 & 112.5 & 28.13 & 0.5 \\
\hline $10 \%$ SCBWP & 75 & 56.25 & 112.5 & 28.13 & 0.5 \\
\hline
\end{tabular}

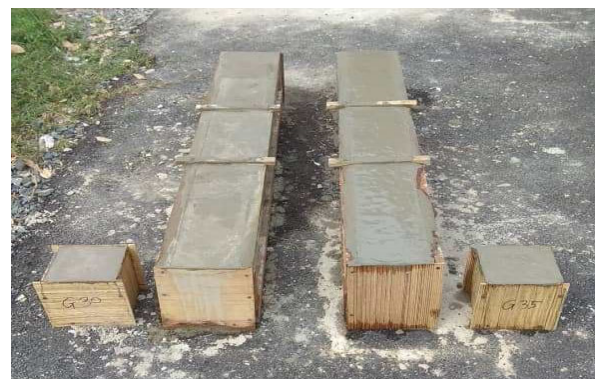

Figure 4: $0 \% \mathrm{C}$ RCB casting

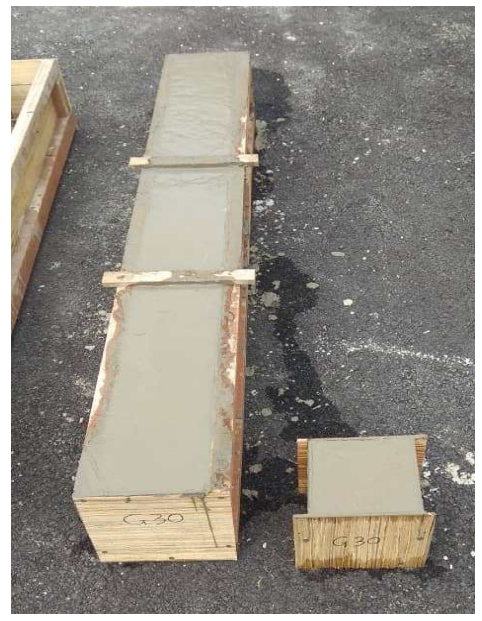

Figure 5: 10\% SCPWP RCB casting

The structural behaviour that is load-deflection and ultimate load bearing capacity were investigated using RCB with a size of $1500 \mathrm{~mm}$ length $\times 150 \mathrm{~mm}$ wide $\times 200 \mathrm{~mm}$ height. Figure 7 and 8 show the RCB detailing and details of cross-section. Air curing was imposed on all the specimens. The RCB load-deflection and ultimate load bearing capacity were determined by performing a four-point flexural test using a MST hydraulic machine with a maximum load capacity of $300 \mathrm{kN}$ in the Universiti Malaysia Pahang's (UMP) concrete laboratory. The RCB was carefully placed on the MST hydraulic machine using a forklift and tested statically under a four-point flexural test. The three linear variable differential transducers (LVDT) mounted on the RCB's mid-span measured the RCB deflection values. The load was applied at a constant moment region. The applied load was measured using a load cell throughout the test and collected using a device called TDS 302 data acquisition. Figure 9 and 10 show the schematic drawing of RCB test setup and RCB test setup at the UMP's concrete laboratory. 


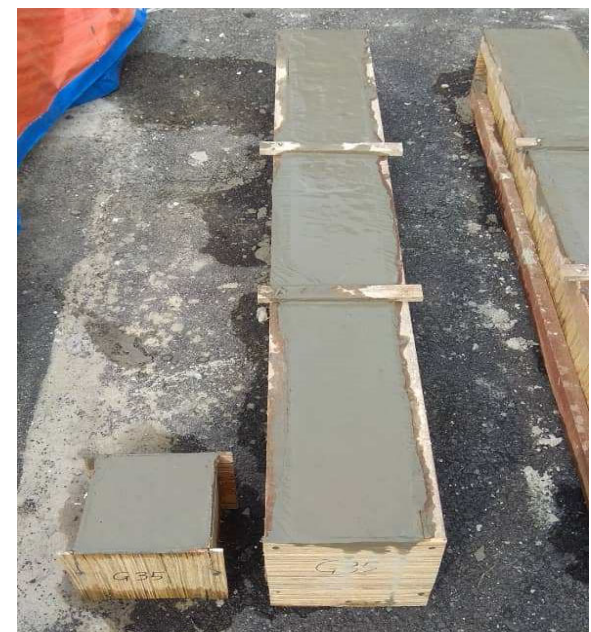

Figure 6: $10 \%$ SCBWP RCB casting

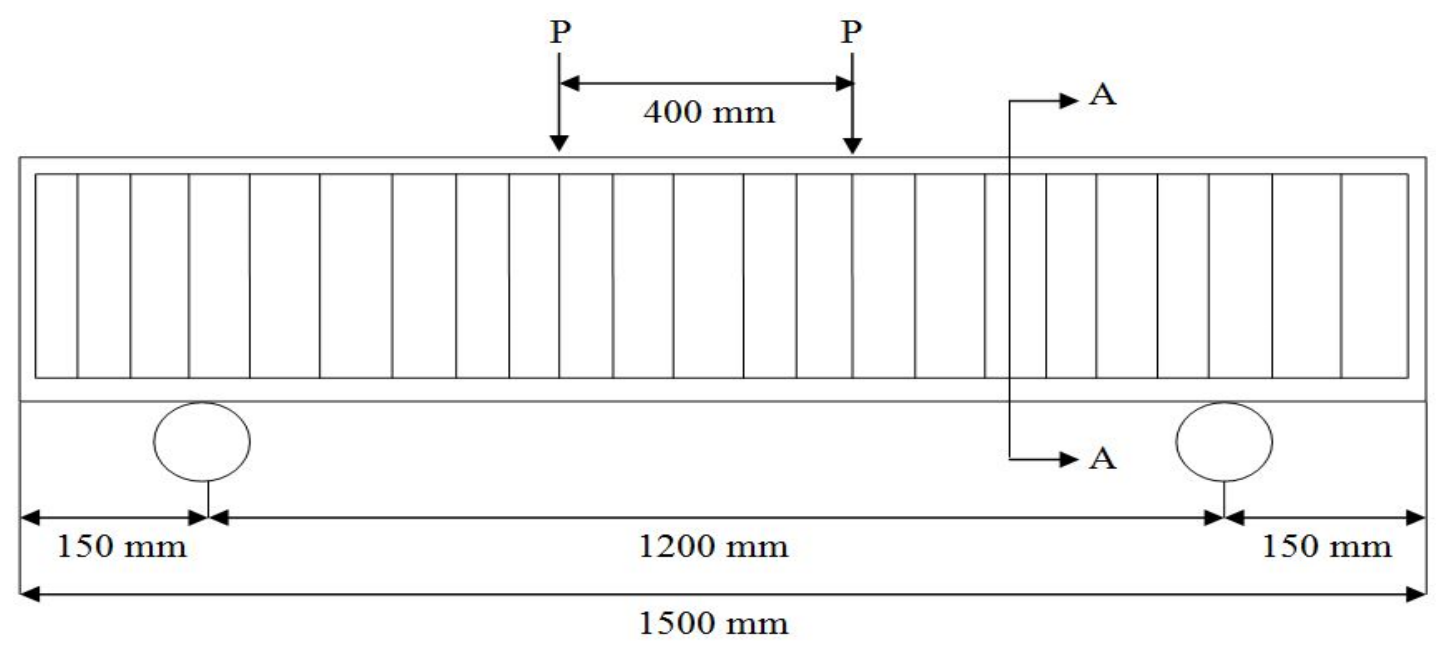

Figure 7: RCB detailing

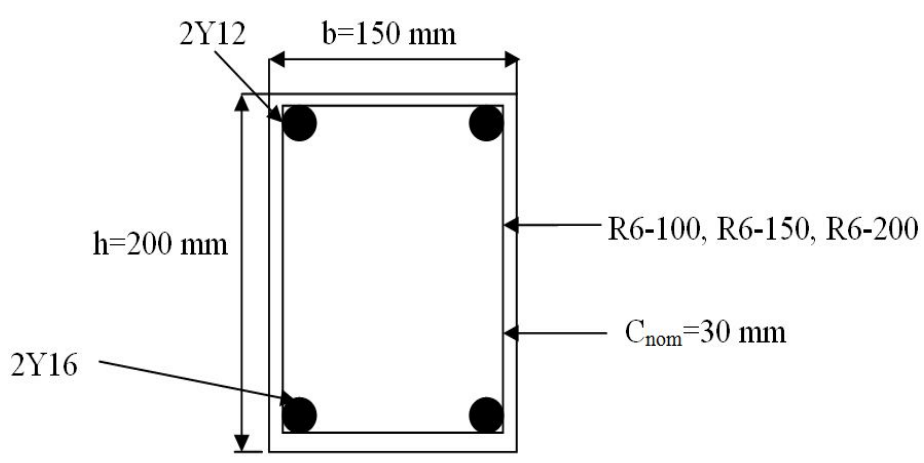

Figure 8: Details of cross-section A-A 


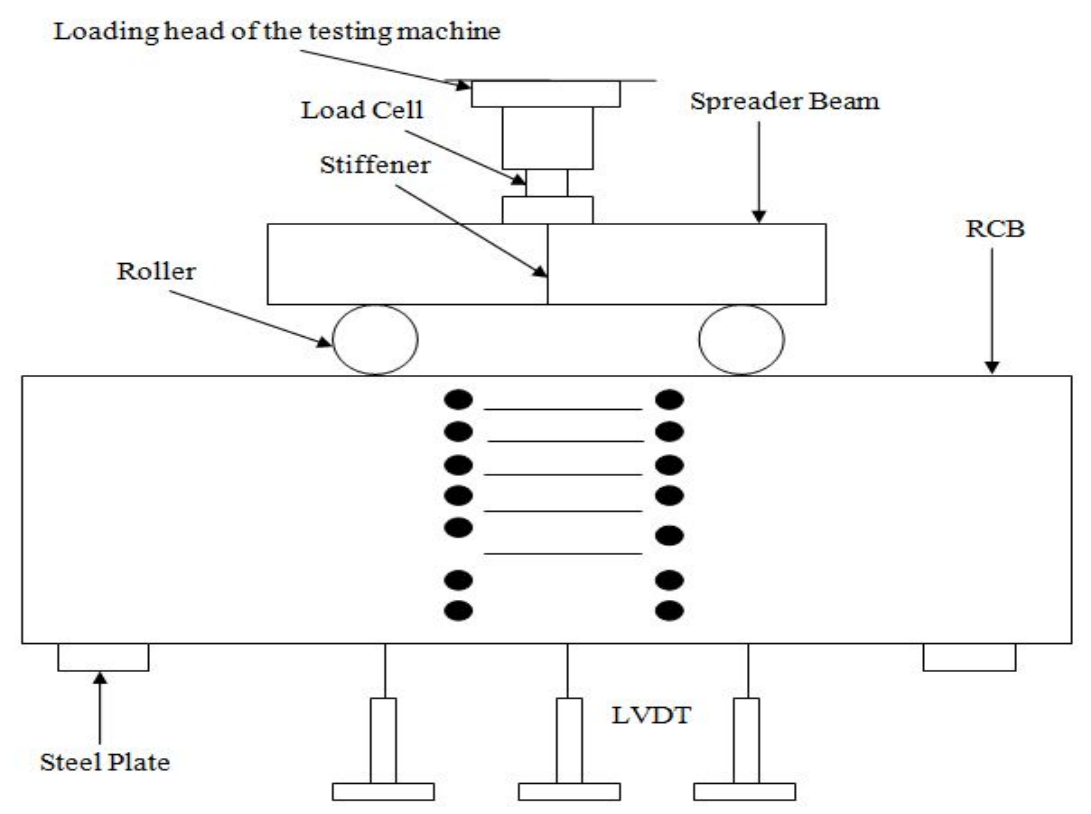

Figure 9: Schematic drawing of RCB test setup

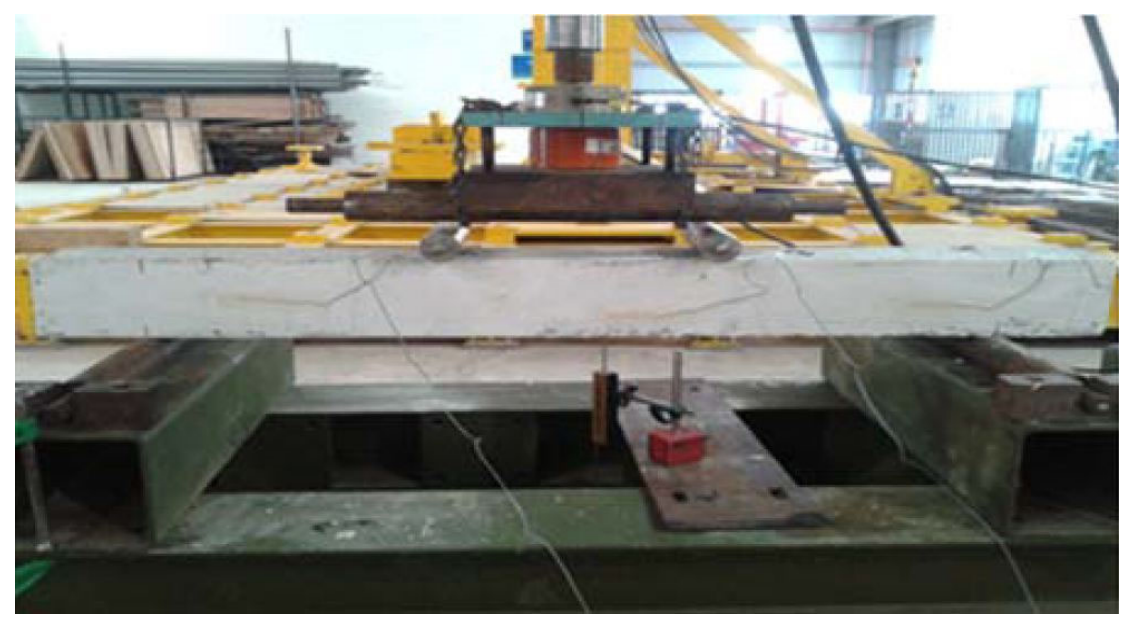

Figure 10: RCB test setup

\section{RESULTS AND DISCUSSION}

\subsection{Load-Deflection}

Figure 11 shows the load-deflection curve of RCB with full shear reinforcement with SS=100 $\mathrm{mm}$ at 28 days with air curing. Table 7 shows the values of load at yield (Py), ultimate load (Pu) and maximum load (Pmax), yield deflection ( $\delta \mathrm{y})$, ultimate deflection $(\delta \mathrm{u})$, maximum deflection $(\delta \max )$ and ductility ratio $(\mu=\delta \mathrm{u} / \delta \mathrm{y})$ of the $\mathrm{RCB}$ with SS$=100 \mathrm{~mm}$. The specimen result is affected by the types of SWP and SS. The load-deflection increases with 10\% SCPWP and 10\% SCBWP addition in the concrete mixture with SS $=100 \mathrm{~mm}$. The $10 \%$ SCBWP records the highest Py, Pu, Pmax and the lowest $\delta \mathrm{y}=, \delta \mathrm{u}, \delta \mathrm{max}$ compared to $10 \%$ SCPWP and 0\% C. 10\% SCBWP records Py=96.67 kN, Pu=103.15 kN, $P \max =106.78 \mathrm{kN}$, which are the highest and $\delta y=11.98 \mathrm{~mm}, \delta \mathrm{u}=23.04 \mathrm{~mm}, \delta \mathrm{max}=18.12 \mathrm{~mm}$, which are the lowest compared to $10 \%$ SCPWP and $0 \%$ C. $0 \%$ C records $P y=89.01 \mathrm{kN}, \mathrm{Pu}=90.23 \mathrm{kN}$, 
Pmax $=100.12 \mathrm{kN}$, which are the lowest and $\delta \mathrm{y}=13.12 \mathrm{~mm}, \delta \mathrm{u}=25.03 \mathrm{~mm}, \delta \mathrm{max}=20.27 \mathrm{~mm}$, which are the highest compared to $10 \%$ SCPWP and 10\% SCBWP. For 10\% SCPWP, Py, Pu, Pmax increase to $4.87 \%, 7.02 \%, 3.33 \%$, while for $10 \%$ SCBWP, increase to $8.61 \%, 14.32 \%, 6.65 \%$ respectively in comparison with $0 \%$. The $\delta \mathrm{y}, \delta \mathrm{u}, \delta \max$ decrease to $4.19 \%, 2.76 \%, 4.05 \%$ for $10 \%$ SCPWP and $8.69 \%$, $7.95 \%, 10.61 \%$ for $10 \%$ SCBWP compared to $0 \% \mathrm{C}$.

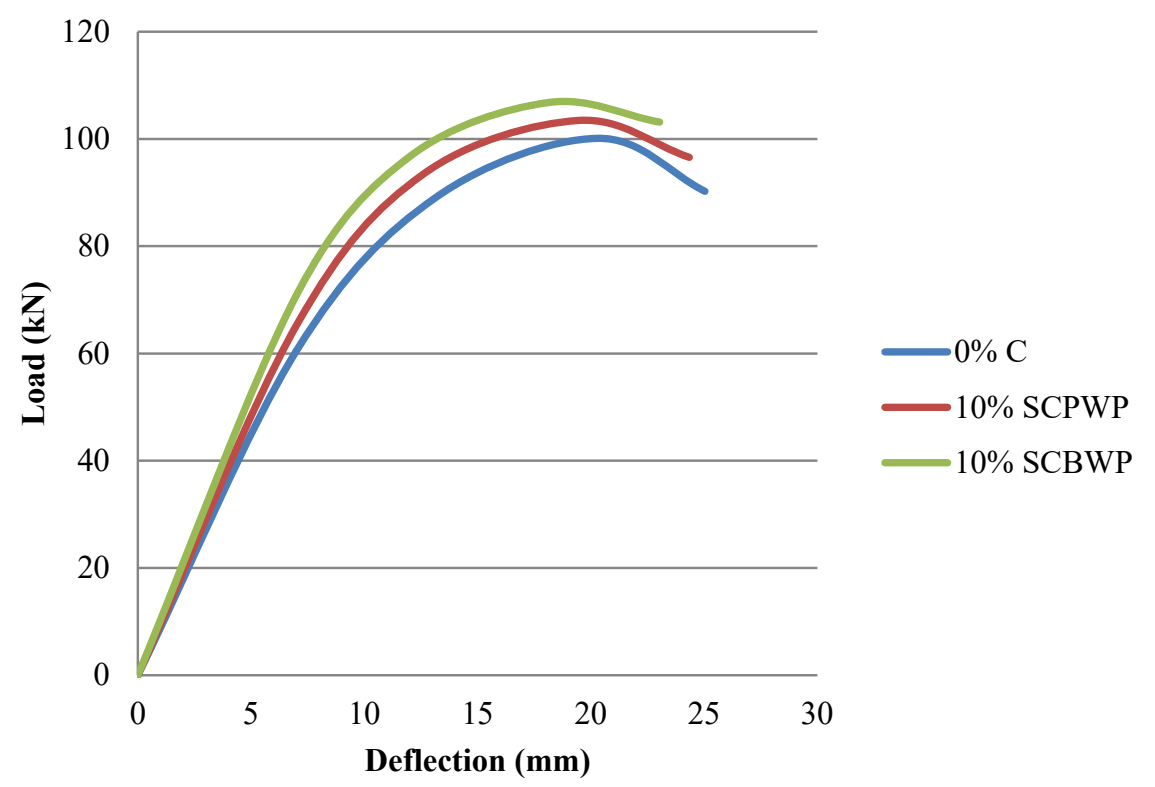

Figure 11: Load-Deflection curve of RCB with full shear reinforcement with $\mathrm{SS}=100 \mathrm{~mm}$

Table 7: RCB test result with full shear reinforcement with $\mathrm{SS}=100 \mathrm{~mm}$

\begin{tabular}{|c|c|c|c|c|c|c|c|}
\hline SWP (\%) & Py $(\mathrm{kN})$ & $\delta \mathrm{y}(\mathrm{mm})$ & $\mathrm{Pu}(\mathrm{kN})$ & $\delta \mathrm{u}(\mathrm{mm})$ & $\operatorname{Pmax}(\mathrm{kN})$ & $\begin{array}{c}\delta \max \\
(\mathrm{mm})\end{array}$ & $\begin{array}{c}\mu= \\
\delta \mathrm{u} / \delta \mathrm{y}\end{array}$ \\
\hline $\begin{array}{c}0 \% \mathrm{C} \\
\begin{array}{c}10 \% \\
\text { SCPWP }\end{array}\end{array}$ & 89.01 & 13.12 & 90.23 & 25.03 & 100.12 & 20.27 & 1.91 \\
\hline $\begin{array}{c}10 \% \\
\text { SCBWP }\end{array}$ & 96.67 & 11.98 & 103.15 & 23.04 & 106.78 & 18.12 & 1.92 \\
\hline
\end{tabular}

Figure 12 shows the load-deflection curve of RCB with reducing shear reinforcement with $\mathrm{SS}=150$ $\mathrm{mm}$ at 28 days with air curing. Table 8 shows the values of load at yield $(\mathrm{Py})$, ultimate load $(\mathrm{Pu})$ and maximum load (Pmax), yield deflection $(\delta y)$, ultimate deflection $(\delta u)$, maximum deflection $(\delta \max )$ and ductility ratio $(\mu=\delta \mathrm{u} / \delta \mathrm{y})$ of the $\mathrm{RCB}$ with $\mathrm{SS}=150 \mathrm{~mm}$. The specimen result is affected by the types of SWP and SS. The load-deflection increases with 10\% SCPWP and 10\% SCBWP addition in the concrete mixture with SS=150 mm. The 10\% SCBWP records the highest $\mathrm{Py}, \mathrm{Pu}, \mathrm{Pmax}$ and the lowest $\delta \mathrm{y}=, \delta \mathrm{u}, \delta$ max compared to $10 \%$ SCPWP and $0 \% \mathrm{C} .10 \%$ SCBWP records $\mathrm{Py}=76.78 \mathrm{kN}, \mathrm{Pu}=81.03 \mathrm{kN}$, Pmax $=84.89 \mathrm{kN}$, which are the highest and $\delta y=9.46 \mathrm{~mm}, \delta \mathrm{u}=18.11 \mathrm{~mm}, \delta \max =13.78 \mathrm{~mm}$, which are the lowest compared to $10 \%$ SCPWP and $0 \%$ C. $0 \% \mathrm{C}$ records $\mathrm{Py}=70.12 \mathrm{kN}, \mathrm{Pu}=72.34 \mathrm{kN}$, $P \max =80.23 \mathrm{kN}$, which are the lowest and $\delta y=10.36 \mathrm{~mm}, \delta u=20.04 \mathrm{~mm}, \delta \mathrm{max}=15.11 \mathrm{~mm}$, which are the highest compared to $10 \%$ SCPWP and 10\% SCBWP. For 10\% SCPWP, Py, Pu, Pmax increase to $4.75 \%, 5.99 \%, 2.90 \%$, while for $10 \%$ SCBWP, increase to $9.50 \%, 12.01 \%, 5.81 \%$ respectively in comparison with $0 \% \mathrm{C}$. The $\delta \mathrm{y}, \delta \mathrm{u}, \delta$ max decrease to $4.73 \%, 4.04 \%, 3.71 \%$ for $10 \%$ SCPWP and $8.69 \%, 9.63 \%, 8.80 \%$ for $10 \%$ SCBWP compared to $0 \%$ C. 


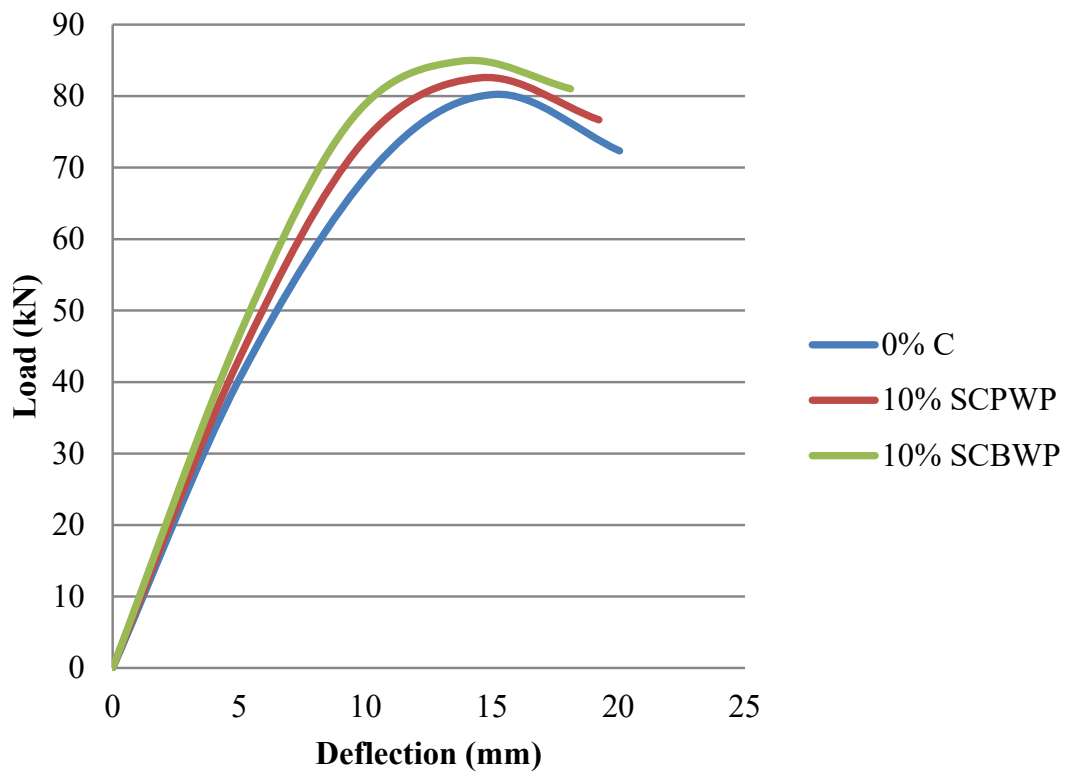

Figure 12: Load-Deflection curve of $\mathrm{RCB}$ with reducing shear reinforcement with $\mathrm{SS}=150 \mathrm{~mm}$

Table 8: RCB test result with reducing shear reinforcement with $\mathrm{SS}=150 \mathrm{~mm}$

\begin{tabular}{|c|c|c|c|c|c|c|c|}
\hline SWP (\%) & Py $(\mathrm{kN})$ & $\delta \mathrm{y}(\mathrm{mm})$ & $\mathrm{Pu}(\mathrm{kN})$ & $\delta \mathrm{u}(\mathrm{mm})$ & $\begin{array}{c}\operatorname{Pmax} \\
(\mathrm{kN})\end{array}$ & $\begin{array}{c}\delta \max \\
(\mathrm{mm})\end{array}$ & $\begin{array}{c}\mu= \\
\delta \mathrm{u} / \delta \mathrm{y}\end{array}$ \\
\hline $0 \% \mathrm{C}$ & 70.12 & 10.36 & 72.34 & 20.04 & 80.23 & 15.11 & 1.93 \\
\hline $\begin{array}{c}10 \% \\
\text { SCPWP }\end{array}$ & 73.45 & 9.87 & 76.67 & 19.23 & 82.56 & 14.55 & 1.95 \\
\hline $\begin{array}{c}10 \% \\
\text { SCBWP }\end{array}$ & 76.78 & 9.46 & 81.03 & 18.11 & 84.89 & 13.78 & 1.91 \\
\hline
\end{tabular}

Figure 13 shows the load-deflection curve of RCB with full shear reinforcement with SS=200 mm at 28 days with air curing. Table 9 shows the values of load at yield $(\mathrm{Py})$, ultimate load $(\mathrm{Pu})$ and maximum load (Pmax), yield deflection ( $\delta \mathrm{y})$, ultimate deflection $(\delta \mathrm{u})$, maximum deflection $(\delta \max )$ and ductility ratio $(\mu=\delta \mathrm{u} / \delta \mathrm{y})$ of the $\mathrm{RCB}$ with $\mathrm{SS}=200 \mathrm{~mm}$. The specimen result is affected by the types of SWP and SS. The load-deflection increases with 10\% SCPWP and 10\% SCBWP addition in the concrete mixture with SS=200 mm. The 10\% SCBWP records the highest Py, Pu, Pmax and the lowest $\delta \mathrm{y}=, \delta \mathrm{u}, \delta$ max compared to $10 \%$ SCPWP and $0 \% \mathrm{C} .10 \%$ SCBWP records $\mathrm{Py}=46.27 \mathrm{kN}, \mathrm{Pu}=60.27 \mathrm{kN}$, $P \max =64.30 \mathrm{kN}$, which are the highest and $\delta y=4.76 \mathrm{~mm}, \delta u=13.27 \mathrm{~mm}, \delta \max =8.98 \mathrm{~mm}$, which are the lowest compared to $10 \%$ SCPWP and $0 \% \mathrm{C} .0 \% \mathrm{C}$ records $\mathrm{Py}=40.36 \mathrm{kN}, \mathrm{Pu}=50.46 \mathrm{kN}, \mathrm{Pmax}=60.51$ $\mathrm{kN}$, which are the lowest and $\delta \mathrm{y}=5.13 \mathrm{~mm}, \delta \mathrm{u}=15.16 \mathrm{~mm}, \delta \mathrm{max}=10.04 \mathrm{~mm}$, which are the highest compared to $10 \%$ SCPWP and 10\% SCBWP. For 10\% SCPWP, Py, Pu, Pmax increase to $7.98 \%$, $9.89 \%, 2.68 \%$, while for $10 \%$ SCBWP, increase to $14.64 \%, 19.44 \%, 6.26 \%$ respectively in comparison with $0 \% \mathrm{C}$. The $\delta \mathrm{y}, \delta \mathrm{u}, \delta \max$ decrease to $4.09 \%, 5.15 \%, 4.78 \%$ for $10 \%$ SCPWP and $7.21 \%, 12.47 \%$, $10.56 \%$ for $10 \%$ SCBWP compared to $0 \% \mathrm{C}$. 


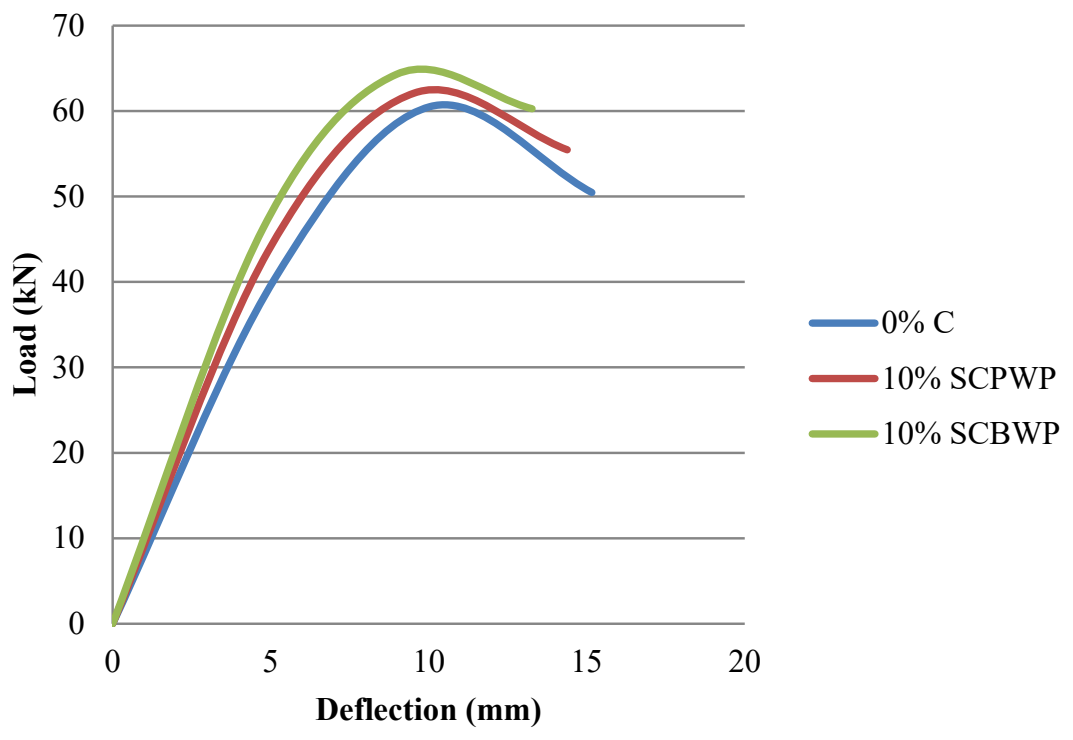

Figure 13: Load-Deflection curve of RCB with reducing shear reinforcement with $\mathrm{SS}=200 \mathrm{~mm}$

Table 9: RCB test result with reducing shear reinforcement with $\mathrm{SS}=200 \mathrm{~mm}$

\begin{tabular}{|c|c|c|c|c|c|c|c|}
\hline SWP (\%) & Py $(\mathrm{kN})$ & $\delta \mathrm{y}(\mathrm{mm})$ & $\mathrm{Pu}(\mathrm{kN})$ & $\delta \mathrm{u}(\mathrm{mm})$ & $\operatorname{Pmax}(\mathrm{kN})$ & $\begin{array}{c}\delta \max \\
(\mathrm{mm})\end{array}$ & $\begin{array}{c}\mu= \\
\delta \mathrm{u} / \delta \mathrm{y}\end{array}$ \\
\hline $0 \% \mathrm{C}$ & 40.36 & 5.13 & 50.46 & 15.16 & 60.51 & 10.04 & 2.96 \\
\hline $\begin{array}{c}10 \% \\
\text { SCPWP }\end{array}$ & 43.58 & 4.92 & 55.45 & 14.38 & 62.13 & 9.56 & 2.92 \\
\hline $\begin{array}{c}10 \% \\
\text { SCBWP }\end{array}$ & 46.27 & 4.76 & 60.27 & 13.27 & 64.30 & 8.98 & 2.79 \\
\hline
\end{tabular}

The result of load-deflection values follows the P1000 \& P9000 standards for less than $1500 \mathrm{~mm}$ span simply supported beam [26]. Nevertheless, the improvement of load at yield (Py) and maximum load (Pmax) of SCPWP and SCBWP RCB with reduced shear reinforcements with SS=150 mm and $\mathrm{SS}=200 \mathrm{~mm}$ are unimportant. The load-deflection curve shows that the $0 \% \mathrm{C} \mathrm{RCB}$ failed earlier as compared to RCB with SS=100 $\mathrm{mm}$ as in Figure 4.9. In addition to that, Pseudo strain hardening effect or multiple cracking behaviour were shown for RCB with SS=100 mm with $10 \%$ SCPWP and $10 \%$ SCBWP. Strain hardening is typical behaviour of metal, but experimental work has been demonstrated that short fibre-reinforced composites often display similar behaviour under increasing load accompanied by multiple cracking due to the arrest of microcrack by fibres [27]. With the addition of fibre to the matrix, the bond between the matrix, dowel action and aggregate interlock mechanism increase and cause the load at yield (Py) to increase. (Martin, 2008) stated that the fibre serves as a cracking mechanism or a crack arrestor after cracking has initiated and causes many cracks, resulting in maximum load (Pmax) to increase [28]. Furthermore, for 10\% SCBWP, the RCB is less deflects compared to the RCB containing 10\% SCPWP and $0 \% \mathrm{C} \mathrm{RCB}$. It is also clear that the lower the shear reinforcements of $\mathrm{SS}=150 \mathrm{~mm}$ and $\mathrm{SS}=200 \mathrm{~mm}$, the lower the ultimate displacement. The major role of adequate fibre plays the rising load at yield (Py), maximum load (Pmax) and pseudo stress hardening RCB effect. SWP enhances the load at yield (Py) and maximum load (Pmax) of RCB's structure. Subsequently, RCB with full shear reinforcement with SS=100 mm containing $10 \%$ SMWP and $10 \%$ SCWP have a significant role of fibre, which improves the RCB structural behavior by showing the pseudo strain hardening (multiple cracking) on the RCB surface. The ultimate deflection ( $\delta \mathrm{u})$ is calculated concerning yield deflection $(\delta y)$ to obtain the ductility ratio $(\mu)$ in this study. 
In general, a high ductility ratio shows that a structural member is able to undergo significant deflection before failure. The reinforced concrete structure ductility is essential because each member should undergo substantial deflection at near maximum load-bearing capacity and provide ample warning when the structure is near faulty. Satisfactory ductility is observed in this research for RCBs with $\mathrm{SS}=100 \mathrm{~mm}$. The findings show a significant increase in ductility of the RCB when sufficient SWP are added to the mixture. The maximum ductility improvement is obtained from the RCB with $\mathrm{SS}=100$ $\mathrm{mm}$ with $10 \%$ SCBWP and cause the ductility increases to $4.68 \%$. For $10 \%$ SCPWP, the ductility increases to $5.47 \%$ compared to $0 \% \mathrm{C} \mathrm{RCB}$. It is investigated that the ductility increases up to a certain point before reducing upon the addition of concrete containing 10\% SCPWP and 10\% SCBWP. (Syed Mohsin, 2012) showed a similar pattern in which the RCB becomes stiff and fails with less ductility due to more fibres added to the RCB [29]. As crack initiates, the fibre prevents crack growth and creates multiple cracks, ultimately increases the ductility. Since the 10\% SCPWP and 10\% SCBWP RCBs are more brittle than the $\mathrm{C} \mathrm{RCB}$, the ductility shows significant improvement in the structural properties of the RCB with the incorporation of SCPWP and SCBWP. The presence of $10 \%$ SCPWP and $10 \%$ SCBWP in RCB structures show the ability to control the propagation of cracks and significantly improve the strength and structure ductility.

\subsection{Ultimate Load Bearing Capacity}

The initial cracking of the $0 \% \mathrm{C}$ RCB took place at a shear distance of $60.47 \mathrm{kN}$. Eventually, $\mathrm{P}_{1}$ occurs at $65.22 \mathrm{kN}$ for $10 \%$ SCPWP and $70.84 \mathrm{kN}$ for $10 \%$ SCWP with full-shear reinforcement with SS=100 $\mathrm{mm}$. There are $7.86 \%$ and $17.15 \%$ difference increases for $10 \%$ SCPWP and $10 \%$ SCBWP compared to $0 \% \mathrm{C}$. The Pu are $90.23 \mathrm{kN}, 96.56 \mathrm{kN}$ and $103.15 \mathrm{kN}$ for $0 \% \mathrm{C}, 10 \%$ SCPWP and $10 \%$ SCBWP. There are $7.02 \%$ and $14.32 \%$ difference increases for $10 \%$ SCPWP and $10 \%$ SCBWP compared to $0 \%$ $\mathrm{C}$. The cracks propagate at two surfaces, which are front and back of the RCB upon load increasing. For $0 \% \mathrm{C}$ with reducing shear reinforcement with $\mathrm{SS}=150 \mathrm{~mm}$, a failure occurs in the shear span of the RCB indicated as a shear failure with $72.34 \mathrm{kN} \mathrm{Pu}$. $76.67 \mathrm{kN}$ for $10 \%$ SCPWP and $81.03 \mathrm{kN}$ for $10 \%$ SCWP. There are $5.99 \%$ and $12.01 \%$ differences increase for $10 \%$ SCPWP and $10 \%$ SCBWP compared to $0 \% \mathrm{C}$. For $\mathrm{P}_{1}, 10 \%$ SCBWP shows a higher value which is $46.50 \mathrm{kN}$ than $10 \% \mathrm{SCPWP}$ and $0 \% \mathrm{C}$, which are $43.24 \mathrm{kN}$ and $40.36 \mathrm{kN}$. There are $7.54 \%$ and $15.21 \%$ difference increases for $10 \%$ SCPWP and $10 \%$ SCBWP compared to $0 \% \mathrm{C}$. On the other hand, the $\mathrm{P}_{1}$ initiates at $20.86 \mathrm{kN}, 24.17 \mathrm{kN}$ and $28.53 \mathrm{kN}$ in shear span for the RCB with reducing shear reinforcement with SS=200 mm with $0 \% \mathrm{C}$, $10 \%$ SMWP and 10\% SCBWP and induces fail in shear at Pu of $50.46 \mathrm{kN}, 55.45 \mathrm{kN}$ and $60.27 \mathrm{kN}$. There are $15.87 \%$ and $36.77 \%$ differences increase for $10 \%$ SCPWP and 10\% SCBWP compared to $0 \% \mathrm{C}$ for $\mathrm{P}_{1}$ and $9.89 \%$ and $19.44 \%$ difference increases for $10 \%$ SCPWP and $10 \%$ SCBWP for Pu. The RCB fails with multiple cracking upon load increasing. Table 10 shows the first crack and ultimate loads for all RCB. The result of $\mathrm{P}_{1}$ and Pu values follows the P1000 \& P9000 standards for less than $1500 \mathrm{~mm}$ span simply supported beam [26].

Table 10: Load at first crack and ultimate load

\begin{tabular}{|c|c|c|c|}
\hline Stirrup Spacing $(\mathrm{mm})$ & Concrete Mixture & $\begin{array}{c}\text { Load at First Crack }\left(\mathrm{P}_{1}\right) \\
(\mathrm{kN})\end{array}$ & $\begin{array}{c}\text { Ultimate Load } \\
(\mathrm{Pu})(\mathrm{kN})\end{array}$ \\
\hline 100 & $0 \% \mathrm{C}$ & 60.47 & 90.23 \\
\hline 100 & $10 \%$ SCPWP & 65.22 & 96.56 \\
\hline 100 & $10 \%$ SCBWP & 70.84 & 103.15 \\
\hline 150 & $0 \%$ C & 40.36 & 72.34 \\
\hline 150 & $10 \%$ SCPWP & 43.24 & 76.67 \\
\hline 150 & $10 \%$ SCBWP & 46.50 & 81.03 \\
\hline 200 & $0 \%$ C & 20.86 & 50.46 \\
\hline 200 & $10 \%$ SCPWP & 24.17 & 55.45 \\
\hline 200 & $10 \%$ SCBWP & 28.53 & 60.27 \\
\hline
\end{tabular}


If reinforced concrete exhibits many cracks and ultimate concrete strength is higher than $\mathrm{P}_{1}$, it may demonstrate pseudo strain hardening or pseudo ductility during increasing tensile load [30]. This result clarifies that fibres are not sufficient to increase the RCB shear strength to prevent shear failure. Besides that, this demonstrates that an adequate quantity of fibre in RCB with reducing shear reinforcement influences the shear failure from occurring. The cracks propagate at the bottom of the RCB and with further increase in load, the flexural failure ensues. Fibre pullout mechanism acts as cracks arrester, increasing the number of cracks at the bottom of the RCB and reducing cracks width. The presence of fibre in the mix, thus increases the tension contribution of concrete and limited diagonal cracks opening. Moreover, (Martin, 2008) said that the fibres control the shear cracks, the mechanism of aggregate interlock, and improve the RCB dowel movement [28]. Furthermore, most other cracks have been found in the 10\% SMWP and 10\% SCWP RCB in a small size to decrease the crack width and increase the number of cracks by the inclusion of fibre. It is obviously evident that fibre increases the tensile characteristic and prevents the crack growth through the pullout mechanism that improves the RCB's structural properties. Thus, the shear reinforcement is enhanced by a sufficient amount of fibre by changing from shear to bending for 10\% SCPWP and 10\% SCBWP RCB failure modes and inhibiting diagonal cracks.

On the other hand, the result shows that fibre is suitably used to control the RCB's crack distribution. There are more cracks form on the RCB as the load increases. The experimental test result also shows that the RCB with fibre increases the load-carrying capacity after cracking. $0 \% \mathrm{C} \mathrm{RCB}$ failure occurs because of insufficient shear strength capacity in shear compression failure. As a result, the fibres are used as a part of shear reinforcement. Both RCB show multiple cracking behaviours with full shear reinforcement with SS=100 mm with 10\% SCPWP and 10\% SCBWP than the other four RCB with reducing shear reinforcements with $\mathrm{SS}=150 \mathrm{~mm}$ and $\mathrm{SS}=200 \mathrm{~mm}$. The crack formations were marked on the RCB, which is inevitably detected from the first crack near to the RCB middle span. The cracks formation on the RCB surface is mainly vertical, suggesting that there is a shear failure occurs. It is noted that the number of cracks increases and there are multiple cracking failures by increasing the amount of fibre. The result shows that the formation of the first crack is mainly affected by the amount of fibre. This first crack formation means that the amount of fibre increases the first cracking load and reduces the crack width. In conclusion, the first cracking load increases and the crack width reduces by the influence of fibre. Subsequently, it is also found that an appropriate amount of fibre increases the RCB strength (Py and Pmax) and changes the RCB failure mode from shear to bending.

\section{CONCLUSION}

The Py, Pu, Pmax and $\mathrm{P}_{1}$ increase with 10\% SCPWP and 10\% SCBWP RCB with full shear reinforcement with $\mathrm{SS}=100 \mathrm{~mm}$ and reduced shear reinforcements with $\mathrm{SS}=150 \mathrm{~mm}$ and $\mathrm{SS}=200 \mathrm{~mm}$ compared to C $0 \%$. 10\% SCBWP RCB records the highest Py, Pu, Pmax and $\mathrm{P}_{1}$ for all types of SS. The $\delta y, \delta u$, and $\delta$ max decrease with $10 \%$ SCPWP and 10\% SCBWP RCB with full shear reinforcement with $\mathrm{SS}=100 \mathrm{~mm}$ and reduced shear reinforcements with $\mathrm{SS}=150 \mathrm{~mm}$ and $\mathrm{SS}=200 \mathrm{~mm}$ compared to $\mathrm{C} 0 \%$. $10 \%$ SCBWP RCB records the lowest $\delta \mathrm{y}, \delta \mathrm{u}$, and $\delta$ max for all types of SS. The $0 \% \mathrm{C}, 10 \% \mathrm{SCPWP}$ and 10\% SCBWP RCB with full shear reinforcement with $\mathrm{SS}=100 \mathrm{~mm}$ records higher $\mathrm{Py}, \delta \mathrm{y}, \mathrm{Pu}, \delta \mathrm{u}$,

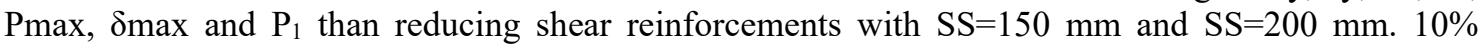
SCBWP RCB records the highest $\mathrm{Py}, \delta \mathrm{y}, \mathrm{Pu}, \delta \mathrm{u}, \mathrm{Pmax}, \delta \max$ and $\mathrm{P}_{1}$. Generally, $10 \%$ addition of SCPWP and SCBWP is the optimum concrete mix proportion. 10\% SCBWP has higher Py, Pu, Pmax and lower $\delta \mathrm{y}, \delta \mathrm{u}, \delta \mathrm{max}$ than $10 \%$ SCPWP for all three types of SS because SCBWP has higher cellulose, more fibre average length, a higher proportion of medium and long fibre contents than SCPWP. Using SWP in concrete and RCB, the paper industry's disposal cost can be saved, and sustainable concrete and RCB can also be produced in the construction and civil engineering fields. The utilization of waste material such as SWP as additional alternative material in concrete and RCB will benefit the environment. The advantage of using this waste material also gives benefit to the economy in term of cost-effectiveness. 


\section{ACKNOWLEDGEMENT}

The authors would like to acknowledge Universiti Malaysia Pahang (UMP) in financially supporting this research through the UMP Postgraduate Research Grant Scheme PGRS200373.

\section{REFERENCES}

[1] Yun H., Jung H., Choi C., "Mechanical Properties of Papercrete Containing Waste Paper", Architectural Institute of Korea, 2007.

[2] Fuller, Fafitis, and Santamaria J. " Structural properties of a new material made of waste paper" Building Integration Solutions (AEI) 2006, pp 1-16.

[3] Titzman L.C., "Analysis of Low Cost Building Material for the Mix Alco Process" Texas A \& M University, 2006.

[4] Wikipedia, The Free Encyclopedia, https://en.wikipedia.org/wiki/Papercrete.

[5] Gunarto A, Satyarno I, Tjokrodimuljo K. Newsprint Paper Waste Exploiting for Papercrete Panel. Institute of Research Center, Gadjah Mada University. 2008.

[6] Bai, J. et al. (2003). Compressive Strength And Hydration of Wastepaper Sludge Ash-Ground Granulated Blastfurnace Slag Blended Pastes. Cement and Concrete Research, Volume 33, Issue 8, August 2003, Pages 1189-1202.

[7] Chin, T.L., et al. (1998). A Novel Method to Reuse Paper Sludge and Co-Generation Ashes from Paper Mill. Journal of Hazardous Materials, Volume 58, Issues 1-3, February 1998, Pages 93 102.

[8] Chun Y. et al. (2006). Pulp and Paper Mill Fibrous Residuals in Excavatable Flowable Fill. International Conference on Sustainable Construction Materials and Technologies, June 2007. Coventry, UK.

[9] Gallardo, R.S., Adajar, M.A. (2006). Structural Performance of Concrete with Paper Sludge as Fine Aggregates Partial Replacement Enhanced With Admixtures. Symposium on Infrastructure Development and the Environment 2006, 7-8 December 2006, SEAMEO-INNOTECH. University of the Philippines, Diliman, Quezon City, Philippines.

[10] Kraus, R.N. et al. (2003). Concrete Containing Recycled Fibers from Pulp and Paper Mills. Sixth CANMET/ ACI International Conference June 2003, Recent Advances in Concrete Technology. Bucharest, Romania.

[11] Naik et al. (2004). Use of Pulp and Paper Mill Residual Solids in Production of Cellucrete. Cement and Concrete Research, Volume 34, Issue 7, July 2004, Pages 1229-1234.

[12] Fuwape, J.E. et al. (2007). Technical Assessment of Three Layered Cement-Bonded Boards Produced From Wastepaper and Sawdust. Waste Management, Volume 27, Issue 11, 2007, Pages 1611-1616.

[13] Okino, E.Y.A. et al. (2000). Utilization of Wastepaper to Manufacture Low Density Boards. Bioresource Technology, Volume 73, Issue 1, May 2000, Pages 77-79.

[14] Shukeri, R. B. and a Naser, A. G. "Concrete Mix with Wastepaper" 2nd international conference on built environment in developing countries (ICBEDC 2008), pp. 567-575.

[15] Mr. Yogesh D. Shermale, Dr. Mahaveer B. Varma IOSR Journal of Mechanical and Civil Engineering (IOSR-JMCE) e-ISSN: 2278-1684, p-ISSN: 2320-334X, Volume 14, Issue 2 Ver. VII (Mar. - Apr. 2017), PP 27-32.

[16] Titzman, L. C., "Analysis of Low Cost Building Material for the Mix Alco Process" Texas \& M University, 2006.

[17] Yogesh D. Shermale, M. B. Varma, "Papercrete: A Lightweight Concrete", Aurangabad, Maharashtra, India, 2016.

[18] Malthy R, Jegatheeswaran D. Comparative study on papercrete bricks with conventional bricks. ICI Journal. January-March 2011.

[19] YTL Cement. 2015. Orang Kuat, YTL Cement (online). https://www.ytlcement.com/bags_orang 
kuat.asp (30 November 2015).

[20] Ms 522 Part 1:2003 Portland Cement (Ordinary and Rapid-hardening) Part 1 Specification (Second Revision)-709539.

[21] British Standards Institution. 1992. Specification for Aggregates from natural sources for concrete: BS 882.

[22] G.V.S. Prasad, P.P. Reddy, M.Swathi, P.D.V.Kumar, T. Praveenraja, M.Naveen, In. J.of Eng. R., 3 (2015).

[23] Iqbal N. Gorgis, Harith M. Zaki, and Shakir A. Salih, Properties of Papercrete, Journal of Engineering and Applied Sciences, Asian Research Publishing Network (ARPN), ISSN 18196608, Vol. 12, No. 24, December 2017.

[24] Harith Zaki, Iqbal Gorgis, and Shakir Salih, Mechanical Properties of Papercrete, Building and Construction Engineering Department, University of Technology, Baghdad, Iraq, BCEE3-2017, MATEC Web of Conferences 162, 02016 (2018).

[25] Piotr Borsyiuk, Danuta Nicewicz, Jerzy Pawlicki, Marcin Klimczewski, The Influence of The Type and Preparation of Ligno-Cellulose Fibres on The Properties of MDF, Faculty of Wood Technology (WTD) SGGW Warszawa, Warsaw, Poland, Wood Research, 79-88, 52 (4): 2007.

[26] No.17A, A Part of Atkore International, Unistrut General Engineering Catalog, 2016.

[27] Li, A. E., Alkhairi, F. M., \& Hammoud, H. 1993. Fiber Reinforced Concrete. ACI Journal. 59: 351-374.

[28] Martin, A. M. 2008. Fibre reinforced cement-based (FRC) composites after over 40 years of development in building and civil engineering. Composite structures, 86(1): 3- 9.

[29] Syed Mohsin, S.M. 2012. Behaviour of fibre-reinforced concrete structures under seismic loading. P.h.D thesis, Imperial College London, UK.

[30] Jiang, P. H. 2003. Tension stiffening and cracking of steel fiber-reinforced concrete. Journal of materials in civil engineering. 15(2):174-182. 